\title{
Information, Bodies, and Heidegger: Tracing Visions of the Posthuman
}

\author{
Bradley B. Onishi
}

Published online: 1 December 2010

C The Author(s) 2010. This article is published with open access at Springerlink.com

\begin{abstract}
Discussion of the posthuman has emerged in a wide set of fields through a diverse set of thinkers including Donna Haraway, Ray Kurzweil, Nick Bostrom, N. Katherine Hayles, and Francis Fukuyama, just to name a few. Despite his extensive critique of technology, commentators have not explored the fruitfulness of Heidegger's work for deciphering the various strands of posthumanism recently formulated in response to contemporary technological developments. Here, I employ Heidegger's critique of technology to trace opposing visions of the posthuman, visions that are both tied intimately to new information technologies. For those seeking to extend humanist ideals, information technologies are employed to extend the vision of an ultra-humanist view of a 'scientific posthuman' that dangerously understands the body to be a forfeitable nuisance, rather than an inherent aspect of being human. Along Heideggerian lines, thinkers such as N. Katherine Hayles and Thomas Carlson have developed an alternative trajectory related to Dasein's Being-in-the-world. This trajectory posits the self as constituted by a lack or abyss, enabling the formulation of a 'mystical posthuman,' celebrating, rather than forfeiting, humanity's embodied existence.
\end{abstract}

Keywords Posthuman Transhumanism · Heidegger $\cdot$ Nick Bostrom · Thomas Carlson · N. Katherine Hayles · Information technologies

\section{Introduction}

Nietzsche's Zarathustra proclaimed, 'Man is something that must be overcome.' Over the last quarter century thinkers from every corner of the academic universephilosophers, critical theorists, science-fiction writers, scientists, literary critics, and others-have come to agree with him. However, for the most part strategies for overcoming the human have not been formulated in terms of the Übermensch, but

B. B. Onishi $(\bowtie)$

Religious Studies Department, University of California Santa Barbara, 729 De La Vina St.,

Santa Barbara, CA 93101, USA

e-mail: bonishi@umail.ucsb.edu 
rather in discourse surrounding the 'posthuman.' Discussion of the posthuman has emerged in a wide set of fields, through a diverse set of thinkers including feminist philosopher Donna Haraway, inventor Ray Kurzweil, transhumanist philosopher Nick Bostrom, literary critic N. Katherine Hayles, and political theorist Francis Fukuyama, just to name a few. Inevitably, with discussion and rumination coming from such different academic contexts, visions of the posthuman vary tremendously. For some, the notion of the the posthuman includes overcoming the humanist dream of a discrete, autonomous subject - it is a way of re-envisioning models of selfhood. For others, the vision is more radical - it could include living a bodiless existence as an avatar in cyberspace, or inhabiting a completely artificial body connected to the brain - it is a means for transforming both body and mind through radical technological innovation. Despite this disparity, two characteristics are constant throughout posthuman discourse.

First, posthumanism must be understood as reflection upon and discussion of humanism. To be somewhat trite, it is natural that one's understanding of the human will inevitably influence their vision of the posthuman. As I will demonstrate below, one can characterize the differing trajectories of posthumanism by placing them into two general camps: ultra-humanists, those who want to extend the humanist project to hyperbolic ends; post-humanists, those that want to overcome the humanist understanding of the human in favor of a revised model. ${ }^{1}$

Second, these theorists agree that if Zarathustra's dream of overcoming the human is to become reality, it will take place through an intimate relationship with the technological, more specifically, with new information technologies. This is no coincidence. During the last quarter century information technologies have accompanied humanity into previously unimaginable subjective and technological territory. Every time one turns on satellite or digital television, uses a card for a cash withdrawal from an automated bank teller, or makes a point of sale purchase at a restaurant, one is using a technology that is able to store, send or transform information over a nonphysical, informational network. All of this is not to mention the most influential and revolutionary information technology that has only been in widespread public use for less than 2 decades - the Internet. For many people all over the globe, the Internet is an integral aspect of daily life as they send e-mails to friends or colleagues, look up information related to work or leisure, join chat rooms with people of similar interests, play various roles in on-line communities, and explore the vast expanse of the Internet's informational space. Quite simply, the proliferation and dissemination of the Internet has changed the ways in which we communicate with other human beings and machines, but more importantly, it has changed how we interpret reality and interpret what it means to be human. In response and in anticipation, theorists from various fields have declared the emergence of the 'posthuman' as a means to account for the developments wrought by these rapidly developing technologies.

In what follows I will employ Heidegger's critique of technology to trace opposing visions of the posthuman, visions that are tied intimately to these technological developments. For those seeking to extend humanist ideals, information technologies

\footnotetext{
${ }^{1}$ The term "humanism" is used in a wide variety of contexts in relationship to a number of different philosophical trajectories. As I discuss in my analysis of Heidegger's critique of technology below, the term is used here in reference to the Cartesian formulation of a worldless ego that is understood to be the basis of modern metaphysics.
} 
are employed to extend the vision of the human as an autonomous, self-legislating subject, standing over against a world of objects. It is an ultra-humanist vision of a 'scientific posthuman.' I will argue below that within this framework the human itself is objectified as it is converted into a calculable and reducible set of informational patterns participating in what Heidegger calls the standing-reserve, albeit in this context, the standing-reserve of information. Following Heidegger, theorists such as $\mathrm{N}$. Katherine Hayles and Thomas Carlson have formulated an alternative trajectory that develops along similar lines to Dasein's Being-in-the-world, positing the self as constituted by a lack or abyss. Within this trajectory a 'mystical posthuman' emerges; networked, multiple, and fluid, it is never fully present, nor decipherable to itself. ${ }^{2}$

\section{Part I: The Standing-Reserve of Information and the Emergence of the Scientific Posthuman}

The ultra-humanist trajectory of the scientific posthuman is illustrated most vividly in the scientific movement called 'transhumanism,' which promotes the radical alteration of human minds and bodies in order to develop a new posthuman species with the potential to transcend current human capabilities. While transhumanism is certainly not the only discourse by which the posthuman has been formulated, it is an appropriate place to investigate the logic underlying formulations of the posthuman based on scientific advancement. Transhumanism is a prevalent posthuman trajectory that represents, in hyperbolic form, the logic of ultra-humanist posthuman discourse. Furthermore, while some of transhumanism's ideas for human enhancement and transformation may seem more apt to a science-fiction novel than serious academic discourse, transhumanism is an influential school of thought, formulated by worldclass scholars from all over the world. ${ }^{3}$

Nick Bostrom, ${ }^{4}$ the director of the Future of Humanity Institute at the James Martin Twenty-first Century School of the University of Oxford, defines transhumanism as follows:

\footnotetext{
${ }^{2}$ My use of the term "mystical posthuman" is indebted to Thomas A. Carlson's analysis in The Indiscrete Image, which draws comparisons between the apophatic anthropology characteristic of certain Christian mystical texts with recent discourse on the posthuman. While the term "mystical" evokes a number of different connotations, in the present context it signifies a subject never fully decipherable to itself-an ineffable and dispossessed subject. It is not meant to imply subjective "mystical experiences" such as visions, revelatory dreams, etc. See, Carlson, T. A. (2009). The indiscrete image: Infinitude and creation of the human. Chicago: University of Chicago Press.

${ }^{3}$ The two most important examples are Ray Kurzweil and Hans Moravec. Kurzweil is a scientist/inventor who has received a $\$ 500,000$ MIT-Lemelson Prize, received 12 honorary doctorates from various universities, as well as received the National Medal of Technology in the United States. He has written a couple of very influential texts, including The Age of the Spiritual Machines: How We Will Live, Work, and Think in the New Age of Intelligent Machines (London: Orion Business, 1999).

Moravec is a scientist at Carnegie-Mellon University who has been researching and creating robots since the 1960s. His book Mind-Children: The Future of Robot and Human Intelligence (London: Harvard University Press, 1988) is one of the seminal texts for the transhuman movement and was one of the first to explain the scientific possibilities of uploading a human mind onto a computer hard drive.

${ }^{4}$ Nick Bostrom is currently the director of the Future of Humanity Institute, which is a member of the James Martin 21st Century School at the University of Oxford, and also a member of the faculty of philosophy at the University of Oxford.
} 
The intellectual and cultural movement that affirms the possibility and desirability of fundamentally improving the human condition through applied reason, especially by developing and making widely available technologies to eliminate aging and to greatly enhance human intellectual, physical, and psychological capacities..$^{5}$

Bostrom is clear that transhumanism understands itself as an heir of the humanist project due to its understanding of individual freedom and autonomy as the highest values of human existence. Thus, for transhumanists, 'It is not our human shape or the details of our current human biology that define what is valuable about us, but rather our aspirations and ideals, our experiences, and the kinds of lives we lead. ${ }^{6}$ These ideals can best be established through the development of technologies that will allow humans to reshape material existence, especially the human body. Brent Waters has argued critically that the main tenets of the transhuman vision are based on the belief 'that the worlds' only underlying and universal feature is information."7 This core belief has serious consequences, as he points out:

Since information has no inherent meaning it can be recast, conveyed and interpreted in virtually endless arrays. The fluidity of information means that all borders are temporary, and any definition permeable. Reality is a construct of shifting patterns of information within and through various media. ${ }^{8}$

Noteworthy is how the technological advances being sought by the transhumanists all share the goal of procuring, processing and distributing information for the purposes of extending the humanist goals of freedom and autonomy to a revolutionary level.

The transhuman ambition for technological advancement is undergirded by an ultra-humanist logic that understands material existence, including the human body, to be a hindrance to the goals of the human/post-human species. The technological advancements proposed by transhumanists aim to reduce all material entities to patterns of information in order to have the freedom to arrange and re-arrange them at an anatomical level. Nanotechnology is based around the notion that microscopic machines will someday be able to arrange and rearrange atoms. Bostrom explains, 'Nanotechnology, by making it possible to rearrange atoms effectively, will enable us to transform coal into diamonds, sand into supercomputers, and to remove pollution from the air and tumors from healthy tissue." Nanotechnology is not unrelated to the second technological development, which is central to the transhuman vision - what Bostrom and others have called 'uploading.' Uploading consists of transferring the informational patterns of a human brain onto a hard drive. ${ }^{10}$ In transferring the brain from the biological body to a computer, all that is needed to retain the identity of the individual would be the successful transfer of the

\footnotetext{
${ }^{5}$ Bostrom, N. (2003). The transhumanist FAQ. Willington, CT: World Transhumanist Association, 4.

${ }^{6}$ Ibid., 4.

${ }^{7}$ Waters, B. (2006). From human to posthuman: Christian theology and technology in a postmodern world. Aldershot: Ashgate, 31.

${ }^{8}$ Ibid.

${ }^{9}$ Bostrom, Transhuman, 9.

${ }^{10}$ Ibid., 17.
} 
informational patterns which were stored on the brain (to another medium): 'The rest is mere jelly. ${ }^{, 11}$ Thus, transhumanists envision posthuman entities that will inhabit prosthetic bodies, or live virtually as avatars in cyberspace. The point is that the body is understood as an outdated model of hardware that needs to be replaced in order to eradicate inherent human deficiencies - hunger, fatigue, disease, and, most of all, death. In order to rectify these deficiencies the human is reduced to a set of informational patterns that can be stored, manipulated, and transformed for the sake of the possibility for limitless posthuman freedom and autonomy.

It is at this critical juncture that Heidegger's notions of 'enframing' and 'the standing-reserve' are helpful for illuminating the consequences of the ultra-humanist logic that undergirds the transhuman vision. While it is true that Heidegger admitted that his critique of technology did not provide a basis for judging it to be defective, Heidegger's critique is helpful for pointing out the relationship between modern technology and the modern metaphysical paradigm instituted by Descartes - a paradigm assumed by transhumanism. I use Heidegger's critique here to point out the specific dangers of the transhumanist vision and to elucidate how alternative visions of the human lead to different conclusions regarding humanity's relationship to technology.

In relation to transhumanism, Heidegger's critique is helpful for the way it illuminates the metaphysical assumptions that structure the movement. Transhumanism is a conscious heir of humanism in that it purports to place the human as the foundation of all values. The movement operates on the assumption of the Cartesian ego as the autonomous, rational Being of beings that is distinct from the world and even its own body. Thus, it is at this point that Heidegger's critique is helpful. By taking the ground of reality to be the individual human consciousnessthe individual ' $\mathrm{I}$ '-Heidegger points out that Descartes effected a fundamental change: 'Man becomes that being upon which all that is, is grounded as regards the manner of its Being and its truth. ${ }^{12}$ With the human subject as the ground of the real, following Nietzsche, Heidegger argues that existence becomes subjected to the subject's endless desire for more freedom and autnonomy - the will to power: 'The ousia (beingness) of the subiectum changes into the subjectness of self-assertive selfconsciousness, which now manifests its essence as the will to will. The will is, as the will to power, the command to more power. ${ }^{13}$ When the will to power is eventually posited as the last metaphysical force governing the ego, the logic of mastery implicit in the Cartesian framework comes to the fore: 'There begins that way of being . . . for the purpose of gaining mastery over that which is as a whole. ${ }^{14}$ Heidegger's point is that if the ego is understood to be the Being of beings, the material world is dominated by the subject's arbitrary will for more power. As a result, the highest values are those related to the freedom and autonomy of the ego - the transhuman vision follows suit by seeking to fulfill these goals through the radical alteration of material existence, including human bodies and brains.

\footnotetext{
${ }^{11}$ Moravec, H. (1988). Mind-children: The future of robot and human intelligence. London: Harvard University Press, 117.

${ }^{12}$ Heidegger, M. (1977). The age of the world picture. In W. Lovitt (Ed.), The question concerning technology and other essays. San Francisco: Harper and Row Publishers, 128.

${ }^{13}$ Heidegger, "The world of Nietzsche: "God is dead". In The question concerning technology and other essays, 88.

14 Ibid.
} 
For Heidegger, this understanding of the human as fundamentally a worldless, Cartesian ego leads to an understanding of the intimate relationship between modern technology and the modern subject. For him, the essence of technology is not technological; its essence is built on the foundation of the human as the Being of beings. As a result, the modern subject naively understands technology as an aid to be used in the will to dominate the objective world: 'The revealing that rules in modern technology is a challenging, which puts to nature the unreasonable demand that it supply energy which can be extracted and stored as such. ${ }^{15}$ Heidegger calls this challenging, 'enframing,' which is the framing of existence within a humanistic structure wherein all entities have meaning only in relation to the human subject.

Yet, technology is never a mere instrument in humanity's service. When the ego becomes the Being of beings, all material entities within the world are evaluated according to a use-value logic in relationship to the ego's desire for limitless power and autonomy:

Everywhere everything is ordered to stand by, to be immediately on hand, indeed to stand there just so that it may be on call for a further ordering. Whatever is ordered about in this way has its own standing. We shall call it the standing-reserve (Bestand). ${ }^{16}$

As a result of this ordering, material entities no longer appear as objects in the world, but are revealed as part of a reserve with which the subject has free reign to use, transform, order, dominate, and destroy for the sake of its own freedom and power. This challenging-forth of the material world changes not only the world picture represented by the subject, but the subject itself. The subject, who was initially the reducer and dominator, becomes reduced and dominated by the logic of the standing-reserve as it becomes 'subordinate to the orderability' of the standingreserve and enables the entities of the standing-reserve to be 'available on demand. ${ }^{17}$ As a result, the human is 'enframed' as another entity to be used within the standing-reserve. This is what Simon Cooper aptly phrases the 'objectification of the subject. ${ }^{18}$

Heidegger's reflections on technology help to explain how the transhuman vision of a 'scientific posthuman' leads to human participation in a new version of the standing-reserve - the standing-reserve of information. For Heidegger the standingreserve is characterized by the storage of raw material, its distribution and its being perpetually re-ordered. The decisive factor regarding information technologies is how they allow subjectivity to be extended into a virtual world that is truly a world beyond and apart from the res extensa. That is, under the rubric of ultra-humanist logic, these technologies facilitate human participation in the standing-reserve of information through the particular manner through which they enable subjective

\footnotetext{
${ }^{15}$ Heidegger, M. (1993). The question concerning technology. In Farrell-Krell D. (Ed.), Basic writings. San Francisco: Harper Collins, 320.

${ }^{16}$ Ibid. For a detailed discussion of the origins of Heidegger's understanding of the standing-reserve, see Zimmerman, M. E. (1991). Heidegger's confrontation with modernity: Technology, politics art. Bloomington, IN: Indiana University Press, 80.

${ }^{17}$ Heidegger, "Technology", 323.

${ }^{18}$ Cooper, S. (2002). Technoculture and critical theory: In service of the machine? London: Routledge, 25.
} 
presence beyond the body. Sherry Turkle's comment on the process of identity construction for those individuals that participate in on-line communities is helpful: 'When people can play at having different genders and different lives, it isn't surprising that for some this play has become as real as what we conventionally think of as their lives, although for them this is no longer a valid distinction., ${ }^{19}$ Information technologies allow the subject to re-arrange patterns of information in order to create a different sense of 'self' - a self constructed of stored informational patterns. As a result, there is a transformation of the experience of the limitations of the body. Buktaman's comment is helpful for illustrating this point:

Through the construction of the computer itself, there arises the possibility of a mind independent of the biology of bodies, a mind released from the mortal limitations of the flesh. . . the invisible processes of cybernetic information circulation and electronic technology construct a body at once material and immaterial - a fundamental oxymoron, perhaps, of postmodernity. ${ }^{20}$

The insertion of the subject into the world of cyber-space has the potential to transform the relation of the subject toward its own sense of embodiment.

However, subjective presence beyond the body in general is not the essential danger of new information technologies, or transhumanism. Following Bukataman's analysis, what remains problematic is the manner in which transhumanism elevates the possibility of a purely informational body to a different level through the transposition of what takes place in cyberspace into the realm of the material world. In other words, the ultra-humanist logic of transhumanism transfers the informational basis of the cyber-world into the material world. Informational patterns and codes make up the substance of existence, including the human body. Consequently, the implicit logic of the humanist framework - the separation of the mind from the body, the mastery of the material world, and the quest for further autonomy and freedom - is extended to a hyperbolic end, and the human itself is taken to be part of the standing-reserve as a reducible and calculable set of informational patterns. The dominant reducer is reduced to ones and zeros.

This posthuman vision is problematic on two levels. First, it follows that if the human, and for that matter, the posthuman, is understood as a re-presentable set of informational patterns, then the ability to ask questions of meaning will have been, to use a Heideggerian term, concealed. In his important, if perplexing text Beiträge Zur Philosophie (Contributions to Philosophy) Heidegger points out that when 'only the representable is,' the only possible goal of human existence can be 'further elaboration' and 'extension and enlargement. ${ }^{21}$ That is, when existence is reduced to that which can be re-presented 'there is nothing question-worthy that could be esteemed through enactment of questioning as such. ${ }^{22}$ If we follow Heidegger here, it seems that the transhuman quest to become posthuman claims to want to give

\footnotetext{
${ }^{19}$ Turkle, S. (1997). Life on the screen: Identity in the age of the internet. New York: Simon and Schuster, 14.

${ }^{20}$ Bukatman, S. (1993). Terminal identity: The virtual subject in postmodern science fiction. London: Duke University Press, 208.

${ }^{21}$ Heidegger, M. (2000). Contributions to philosophy (from Enowning). Bloomington, IN: Indiana University Press, 76.

${ }^{22}$ Ibid.
} 
humans the freedom to pursue their highest values and overcome their greatest deficiencies, yet fails to recognize that by positing the human as a re-presentable, informational participant in the standing-reserve it has already determined the limited frame in which existence can be revealed: 'Where enframing holds sway, regulating and securing of the standing-reserve mark all revealing. ${ }^{23}$ In this case, by reducing existence - including the human - to what Heidegger calls 'the representable,' transhumanism brackets all questions falling outside of the posited goals of enlargement of human freedom and autonomy, which means that questions escaping the purview of these values - questions of telos, meaning, responsibility, or what Heidegger might call 'Being' - are excluded. In sum, everything question-worthy is concealed as the human is transformed into an informational posthuman seeking power, freedom from physical limitations, and its own self-created immortality.

This bracketing of questions of meaning and responsibility points to the second problematic aspect of the transhuman vision. Transhumanism, because it understands the material world, the body, and the human as reducible patterns of information governed by the use-value logic of the standing-reserve, forfeits the human potential for responsibility and singularity. Heidegger's analysis of Dasein demonstrates that it is indeed death that is the singular or irreplaceable aspect of every human being. Heidegger's heirs and critics in the phenomenological tradition remain indebted to this basic insight. As Derrida says: "Irreplaceability is therefore conferred, delivered, "given," one can say, by death...It is from the site of death as the place of my irreplaceability, that is, of my singularity, that I feel called to responsibility. In this sense only a mortal can be responsible. ${ }^{24}$ Mortality constitutes the possibility for singularity and responsibility, whether my own or that of another's. Mortality is a matter of the body. Thus, if we are to avoid taking both the human and the posthuman as participants within the standing-reserve, this basic insight must remain at the fore: Any definition of the human or posthuman that understands the bodyincluding the natality and mortality inscribed therein - as an optional, limiting factor, rather than the topos of responsibility or singularity, leads to the danger of the inclusion of the (post)human within the standing-reserve it is responsible for creating. In response, we must come to an understanding of what remains irreducible regarding the human; we must locate what is beyond, or otherwise than information, in the Information Age.

\section{Part II: Tracing the Mystical Posthuman ${ }^{25}$}

Along Heideggerian lines, an alternative vision of a 'mystical posthuman' has emerged wherein the human is not understood as a representable, self-legislating ego, but as constituted by a fundamental nullity or absence-from-itself. Here, the

\footnotetext{
$\overline{{ }^{23} \text { Heidegger, "Technology," } 332 .}$

24 Derrida, J. (1995). The gift of death, trans. David Wills Chicago: University of Chicago Press, 41.

25 The following discussion is indebted to Thomas A. Carlson's suggestion from chapters 1 and 2 of the Indiscrete Image that Heidegger's critique of ontotheology and modern metaphysics might serve as a helpful starting place for formulating an alternative posthuman trajectory. See also, Carlson, T. A. (2005). Modernity and the mystical: science, technology, and the task of human self-creation. In J. Proctor (Ed.), Science, religion, and the human experience. Oxford: Oxford University Press.
} 
vision of the posthuman is not of a technological extension of the Cartesian ego, with limitless power and autonomy, but a self-absent creature that inhabits a network of relations that it can neither master nor comprehend.

Through his analysis of Dasein in Being and Time, Heidegger attempted to reorient the understanding of the human being, or perhaps more accurately, Being human. In contrast to Descartes' self-grounded ego, Heidegger argues that Dasein is constituted by a fundamental 'nullity.' Dasein is Being-in-the-world: 'As being, Dasein is something that has been thrown; it has been brought into its 'there', but not of its own accord. ${ }^{, 26}$ Dasein's past is one it wasn't present for-one from which it was absent, but which determines its ongoing Being-in-the-world. Thus, Dasein's Being is imbued with a fundamental absence in that Dasein appears always after itself in its thrownness and ahead of itself in its projected possibilities: 'In being a basis - that is, in existing as thrown-Dasein constantly lags behind its possibilities. It is never existent before its basis, but only from it and as this basis. Thus 'Being-abasis' means never to have power over one's ownmost Being from the ground up.' ${ }^{27}$ As a thrown being - as never-present-to-itself-Dasein has been released not 'through itself but to itself.' 28

This self-absence reveals an ineffability that prevents Dasein from ever being reduced to another object in the world. And, indeed, this nullity or absence is in fact the basis of Dasein's Being: 'Care itself, in its very essence, is permeated with nullity through and through. ${ }^{, 29}$ Essential here is how Heidegger's understanding of Dasein has inaugurated a phenomenological trajectory within which the human is understood as passive, ineffable, and always self-creating. To be human is not to be the self-grounded Being of beings, but to be a thrown being with the perpetual task of creating and re-creating itself in interaction with the world that always precedes it. Criticisms of Being and Time aside, important for the present purpose is Heidegger's understanding of the human as constituted by a fundamental nullity - an absencefrom-itself - which stands in opposition to the humanist framework that dominates modern metaphysics.

In texts such as the 'Age of the World Picture,' 'The Question Concerning Technology,' 'Gelassenheit,' Contributions to Philosophy, and other works, Heidegger demonstrates the inherent connection between the modern subject and the will to mastery embodied in modern technology. Yet, Heidegger never explicitly suggests that the interpretation of the human set forth in Being and Time could be matured and furthered in convergence with the technological. Heidegger does assert that modern technology is somehow related to Being, but is unclear as to how this is so. In characteristically opaque fashion, he says in the Memorial Address: 'I call the posture in virtue of which we hold ourselves open for the concealed meaning of the technological world openness towards the Mystery. ${ }^{30}$ I want to suggest that some of what Heidegger implies here-this openness to the mystery of the meaning of technology - has emerged in the work of theorists such as N. Katherine Hayles and

\footnotetext{
${ }^{26}$ Heidegger, M. (1962). Being and time, trans. John Macquarrie and Edward Robinson. San Francisco: Harper and Row Publishers, 329.

27 Ibid., 330.

${ }^{28}$ Ibid., 330.

${ }^{29}$ Ibid., 331.

${ }^{30}$ Heidegger, M. (1959). Discourse on thinking. New York: Harper and Row Publishers, 55.
} 
Thomas Carlson, who have formulated self-absent understanding of the human in convergence with changing conceptions of subjectivity wrought by the development of new information technologies.

Hayles and Carlson have argued that new technological developments can be interpreted as purveyors of a posthuman that does not extend the humanist subject to hyperbolic end (as in the transhuman vision), but reveals a dispossessed, networked and perpetually self-creating postmodern subject related to Heidegger's self-absent Dasein. Hayles explains:

But the posthuman does not really mean the end of humanity. It signals instead the end of a certain conception of the human, a conception that may have applied, at best, to that fraction of humanity who had the wealth, power, and leisure to conceptualize themselves as autonomous beings exercising their will through individual agency and choice. ${ }^{31}$

Within this alternative trajectory, the posthuman marks the end of the self-certain ego in favor of a new model of subjectivity inscribed in what Hayles describes as 'interactive processes from which both mindbody and world emerge together., ${ }^{32}$ Hayles's vision of a being created out of the relationship of mind, body and world resembles the Dasein that inhabits a world that preceded it, one in which it was thrown without choice, will or consciousness, and yet must perpetually render itself in terms of its future possibilities. Dasein is thus always 'beyond itself'-lagging behind its immemorial past as a thrown being, and projecting ahead of itself toward an unactualizable future possibility in death. Forced back upon itself in its possibilities, Dasein must re-create itself in each moment in terms of its future possibilities handed over to it by the past for which it was not present. Similarly, Hayles's posthuman participates in the perpetual process of self-creation in relationship with mind, body, and world, albeit in a framework tied intimately to the technological and, more specifically, information technologies. For both Heidegger and Hayles, the perpetual creation and re-creation of the self is constituted by human mortality. Hayles summarizes her position:

If my nightmare is a culture inhabited by posthumans who regard their bodies as fashion accessories rather than the ground of being, my dream is a version of the posthuman that embraces the possibilities of information technologies without being seduced by fantasies of unlimited power and disembodied immortality, that recognizes and celebrates finitude as a condition of a human being, and that understands human life is embedded in a material world of great complexity, one on which we depend for our continual survival. ${ }^{33}$

Temporality prevents humanity from ever reaching a point of existential homeostasis. In anticipating the possibility of one's own impossibility, the self is forced again and again beyond itself.

\footnotetext{
${ }^{31}$ Hayles, N. K. (1999). How we became posthuman: Virtual bodies in cybernetics, literature, and informatics. Chicago: University of Chicago Press, 286.

${ }^{32}$ Hayles, N. K. (2003). Flesh and metal: reconfiguring the mindbody in virtual environments. In R. Mitchell (Ed.), Data made flesh: Embodying information. London: Routledge, 246.

${ }^{33}$ Hayles, Posthuman, 5.
} 
Following Hayles's implicit adoption of Heideggerian motifs in order to formulate a vision of a post-humanist posthuman, Thomas Carlson has explicitly engaged both Heidegger's early work in Being and Time and later texts on technology in order to envision a posthuman that offers an alternative to the ontotheological lineage of the modern subject. His analysis points to how Heidegger's Being-towards-death orients Dasein toward a horizon that is never determined. One's own death cannot be predicted, nor represented. It is paradoxically Dasein's ownmost possibility and the possibility of its impossibility. Carlson explains,

Heidegger comes to highlight the sense in which human Dasein, or therebeing, is in fact never simply 'there' in the discrete presence of a present. Existent life implies the openness of a possibility that is, so long as life lives, never yet determinate or actually present - and hence an ongoing departure, and irreducible danger, that would inhere in all existent life still to be lived. ${ }^{34}$

For Carlson, the irreducibility of the constitutive horizon of Dasein means that human life is characterized by perpetual indeterminacy.

This reading of Heidegger's Dasein leads to a discussion of Heidegger's work on technology. As suggested above, Carlson asks if technology might not be used as an extension of modern metaphysics, but as a re-opening of the question of the human. Here, human interaction with information technologies highlights the indeterminacy and irreducibility of human life. Within this trajectory, the multiple, fluid, and networked identities enabled by information technologies do not mark human participation within the standing-reserve of information, but rather uncover the selfabsence of the human in a revolutionary manner. Rather than subjecting the human to conditions of tyrannical and total calculation, these new technologies have the ability to reveal the mortal ineffability that lies at the center of the human, a mortality that prevents the human from ever being reducible to calculable or representational terms. For Carlson, instead of revealing the human as a conglomerate of informational patterns, the emergence of the posthuman signals the irreducibility of the human to mere information in and among the Information Age.

The question remains as to what change the post-humanist, mystical approach taken by Hayles and Carlson might actually have on human/posthuman interaction with information technologies. In Heideggerian terms, is an 'authentic' posthuman existence is really possible? Can the networked, dispersed postmodern subjects described by Hayles and Carlson enjoy an authentic existence while living wired, cybernetic lives?

Carlson addresses this question by pointing out that for Heidegger the ownmost possibility of Dasein - its own death-leads to an irreducible indeterminacy akin to inauthenticity: 'Authentic life, along these lines, might imply an insurmountable inauthenticity; my "own" or my "ownmost" "property" might entail that which I can, in fact, never possess. ${ }^{35}$ The authentic life is not one in which Dasein takes possession of its identity. Instead, it is a perpetual rendering with the mortal indeterminacy that constitutes the human as irreducible. As a result, for Carlson

\footnotetext{
${ }^{34}$ Carlson, Indiscrete, 79.

${ }^{35}$ Carlson, Indiscrete, 75.
} 
information technologies can remind the posthuman Dasein of its lack of possession in the face of a world that precedes it, and will continue after its death. Of course, Dasein's dispersion within multiple, overlapping biological, historical, and informational networks can lead to a mindless inauthentic life devoid of authentic reflection. However, it can also lead to moments of 'genuine amazement and truly selfreflective questioning' wherein Dasein is thrown back upon its thrownness; moments that highlight how its identity is a perpetual work of creation and recreation that ultimately leave Dasein ineffable to others and itself. ${ }^{36}$

Of course, mortality does not ensure authenticity or responsibility, as Heidegger's own political involvements demonstrate. Hayles and Carlson posit visions of the mystical posthuman that do not preclude authentic existence, or guarantee it. Their formulations aim to keep open the possibility of authentic existence through a recognition of how the body, including the natality and mortality inscribed therein, constitute the openness, possibility, and self-creative potential of being human/ posthuman. Certainly, inauthenticity is not a function of the advent of information technologies. However, there is no doubt that in many respects information technologies have grossly enlarged the resounding rabble of the they-self by providing access to a limitless sea of information at high rates of speed. The importance of this alternative vision of the posthuman lies not in its guarantee of posthuman authenticity, but in keeping open the horizon upon which it is possible. By doing so, Hayles and Carlson provide a trajectory for understanding how human beings can exist in and with information technologies, without having to choose between a Neo-Luddite boycott, or worse, a transhuman movement that promotes the transformation of the human into a scientific posthuman with no means of asking questions of responsibility, telos or transcendence.

Open Access This article is distributed under the terms of the Creative Commons Attribution Noncommercial License which permits any noncommercial use, distribution, and reproduction in any medium, provided the original author(s) and source are credited.

36 Ibid., 81 . 